
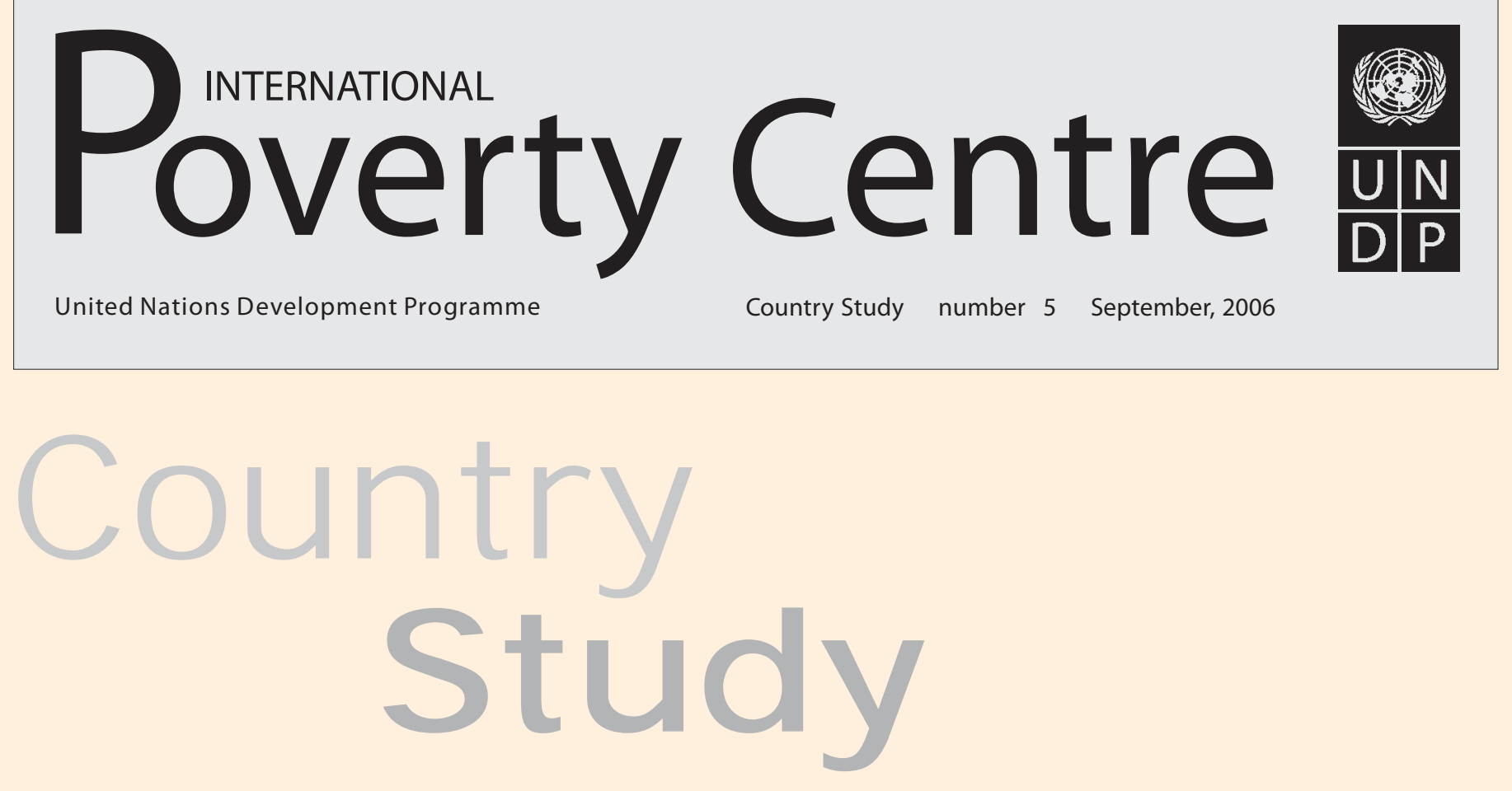

\title{
DOES DEBT RELIEF INCREASE FISCAL SPACE IN ZAMBIA?
}

\section{THE MDG IMPLICATIONS}

Country Study published by IPC, $n^{\circ} 5$

John Weeks

Professor Emeritus,

School of Oriental and African Studies,

University of London

and

Terry McKinley

Senior Researcher and Acting Director, International Poverty Centre,

United Nations Development Programme 


\title{
Copyright $(\subset) 2006$
}

United Nations Development Programme International Poverty Centre

\author{
International Poverty Centre \\ $\mathrm{SBS}-\mathrm{Ed}$. BNDES, $10^{\circ}$ andar \\ 70076900 Brasilia DF \\ Brazil
}

povertycentre@undp-povertycentre.org

www.undp.org/povertycentre

Telephone +55 6121055000

Fax +55612105 5001

\section{Rights and Permissions}

All rights reserved.

The text and data in this publication may be reproduced as long as the source is cited. Reproductions for commercial purposes are forbidden.

The International Poverty Centre disseminates these Country Studies to encourage the exchange of ideas about development issues. These studies are signed by the authors and should be cited standard accordingly. The findings, interpretations, and conclusions that they express are those of the authors. They do not necessarily represent the views of the International Poverty Centre or the United Nations Development Programme, its Administrator, Directors, or the countries they represent.

Country Studies are available online at http://www.undp.org/povertycentre and subscriptions can be requested by email to povertycentre@undp-povertycentre.org 


\title{
DOES DEBT RELIEF INCREASE FISCAL SPACE IN ZAMBIA? THE MDG IMPLICATIONS
}

\author{
John Weeks* and Terry McKinley**
}

This Country Study critically examines fiscal policies in Zambia, particularly the effect of recent and projected debt relief on 'fiscal space'. The study finds that due to associated policy conditionalities and other factors, HIPC debt relief will result in less fiscal space, rather than more. And projected G-8 debt relief will only marginally expand fiscal space. Part of the problem is that the Zambian government has little leeway to choose its own fiscal policies, despite donor rhetoric about 'national ownership' of poverty-reduction policies. Drawing on the analysis of a national study, the Country Study also estimates the additional public expenditures that would enable Zambia to reach the MDGs. In order to finance these expenditures, it proposes a diversified strategy of increasing tax revenue, expanding the fiscal deficit and obtaining more ODA. Finally, it recommends core elements of an expansionary macro framework that could support a seven per cent rate of economic growth (needed to attain MDG \#1, i.e., halving extreme income poverty) and buttress the government's effort to reach the other MDGs. In the process, it seeks to dispel common fears about the possible adverse effects of such fiscal expansion.

\footnotetext{
* Professor Emeritus, School of Oriental and African Studies, University of London.

** Senior Researcher and Acting Director, International Poverty Centre, United Nations Development Programme.
} 


\section{INTRODUCTION}

This Country Study examines fiscal policy in Zambia, and how expenditure and taxation could be used to accelerate growth and reduce poverty. Since 1990, fiscal policy has been closely linked to debt servicing and constrained by external loan conditionalities. Throughout the 1990 s and 2000s, government expenditure was derivative, in effect, from the servicing of external debts.

This inversion of social priorities has had a debilitating effect on growth, poverty reduction and combating the HIV/AIDS pandemic. However, in mid-2006 it appeared that the debt burden had been reduced to less than US\$ one billion, relieving this constraint. ${ }^{1}$ Surprisingly, and regrettably, the net fiscal gain from debt relief has been marginal because of the external policy conditionalities linked to the relief and associated ODA.

If policy conditionalities set by external agencies were more flexible, Zambia could potentially fully achieve all of the MDGs by 2015 . The most challenging would be the poverty reduction goal (MDG \#1) because it would require robust growth well above historical rates. Meeting the MDGs would also require a substantial increase in government expenditure, supported by donors and lenders and a radical change in their approach to conditionality.

In its MDG progress report for 2005, the UNDP categorised achieving the MDGs as 'likely' for five goals, 'potential' for three, and 'unlikely' for two. While this record represented a substantial improvement from the prospects in 2003 (when the corresponding numbers were zero, eight and two, respectively), it implied that half of the MDGs might not be achieved (UNDP 2005).

A recent careful and thorough study of the resource cost of achieving the MDGs provides a rough but reliable estimate of the fiscal effort that the government must undertake (Mphuka 2005). ${ }^{2}$ On the basis of this study and an analysis of the potential for expanding fiscal space over the years 2006-2015, this Country Study proposes a financing package that could realise the MDGs. To lay the basis for the discussion of financing, this Study first considers debt and the balance of payments.

\section{DEBT AND THE BALANCE OF PAYMENTS}

It is no mystery why Zambia accumulated a massive external debt during the last 30 years of the twentieth century: the debt was caused by falling copper prices and the loss of transport links due to Zambia's commitment to the liberation struggles in the Central and Southern African region. ${ }^{3}$ While many sub-Saharan African countries suffered from debilitating debt burdens, for few would the problem be as severe as for Zambia.

Furthermore, few countries waited as long as Zambia to achieve debt reduction under the Heavily Indebted Poor Country (HIPC) initiative. In December 2000, Zambia reached the so-called 'decision point', formally qualifying for HIPC relief. However, the 'completion point' would come over four years later, in April 2005, when the external debt was slightly larger than at the decision point.

Figure 1 shows Zambia's external debt service as a share of export earnings and the average for other sub-Saharan African countries during 1975-2004. The figure does not include 2005 and 2006, when debts were reduced dramatically, first by reaching the HIPC completion 
point in 2005 and second through the promise of G-8 relief in 2006. Only during the second half of the 1980s did Zambia's debt-to-export ratio fall below that of the cross-country average. The figure highlights the startling situation of the early 1990s, when the adjustment programmes of the IMF and the World Bank were associated with four years of debt service ratios in excess of 25 per cent.

FIGURE 1

\section{External Debt Service as Percentage of Exports, Zambia and Other Sub-Saharan African Countries, 1975-2004}

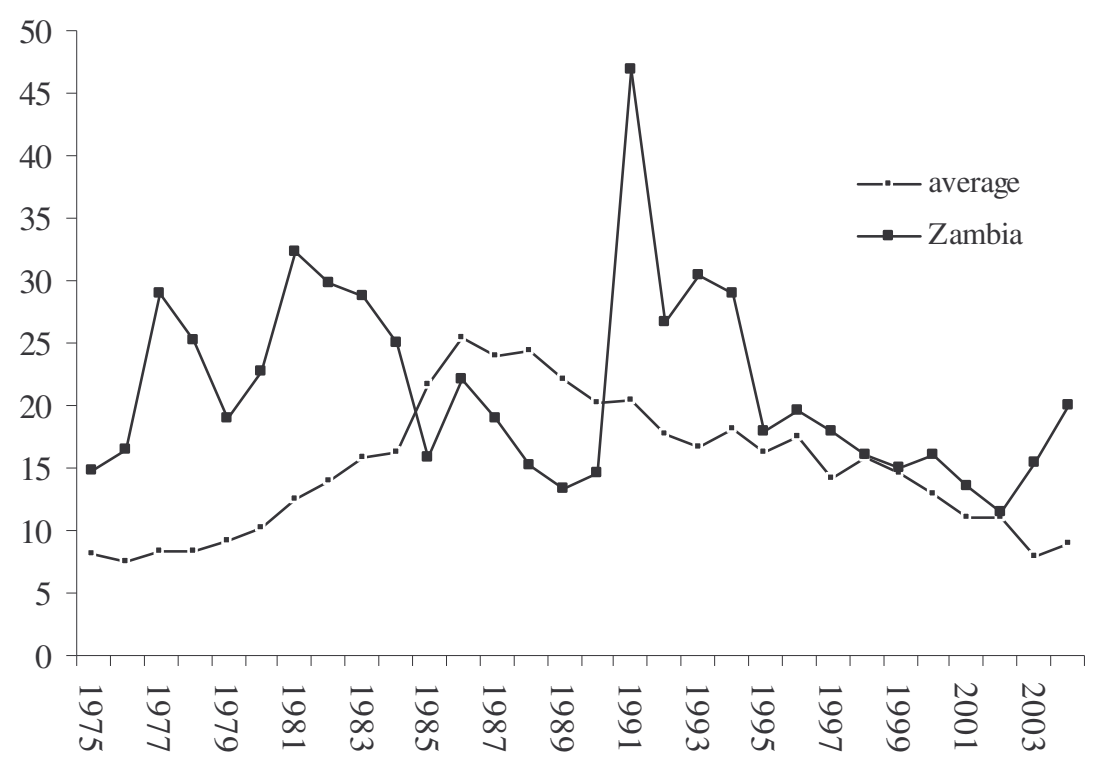

Sources: Ministry of Finance and National Planning, Macroeconomic Indicators (1997-2005), IMF (2004b, 2004c, 2005a \& 2005b), World Bank World Development Indicators (web site).

Even more striking is Figure 2, which shows debt service as a ratio to GDP. This ratio averaged almost nine per cent of GDP for Zambia for over 30 years, double the ratio for the other African countries. The adjustment programmes did little to change this: the average for Zambia after 1990 was only marginally less than for previous years. To put such a debt service to GDP ratio in perspective, during the Latin American debt crisis of the 1980s, only three of 18 countries had ratios for a decade above Zambia's average for three decades.

Measured per capita, Zambia's debt burden appears even more onerous. Figure 3 compares Zambia to other sub-Saharan African countries, but over a slightly shorter period, 1980-2004, and on the basis of three-year moving averages to reduce the effect of the extreme values of the 1990s. ${ }^{4}$ In current U.S. dollars, the difference between Zambia and the other countries is stiking: a 25-year average of US\$ 720 for Zambia and US\$ 466 for the other countries. However, these numbers understate the difference between Zambia and the other African countries because of terms of trade changes. Since debts must ultimately be repaid by exports, a decline in export prices raises the real value of debt.

When per capita debt is adjusted for the terms of trade, the average for the other subSaharan African countries declines slightly, to US\$ 450, while that for Zambia increases dramatically, to over US\$900. Instead of being slightly lower after 1990 than before (when current prices were used), the per capita debt, adjusted for the terms of trade, increases from US\$ 730 to US\$ 1030. 
FIGURE 2

External Debt Service as Percentage of GDP, Zambia and Other Sub-Saharan African Countries, 1975-2004

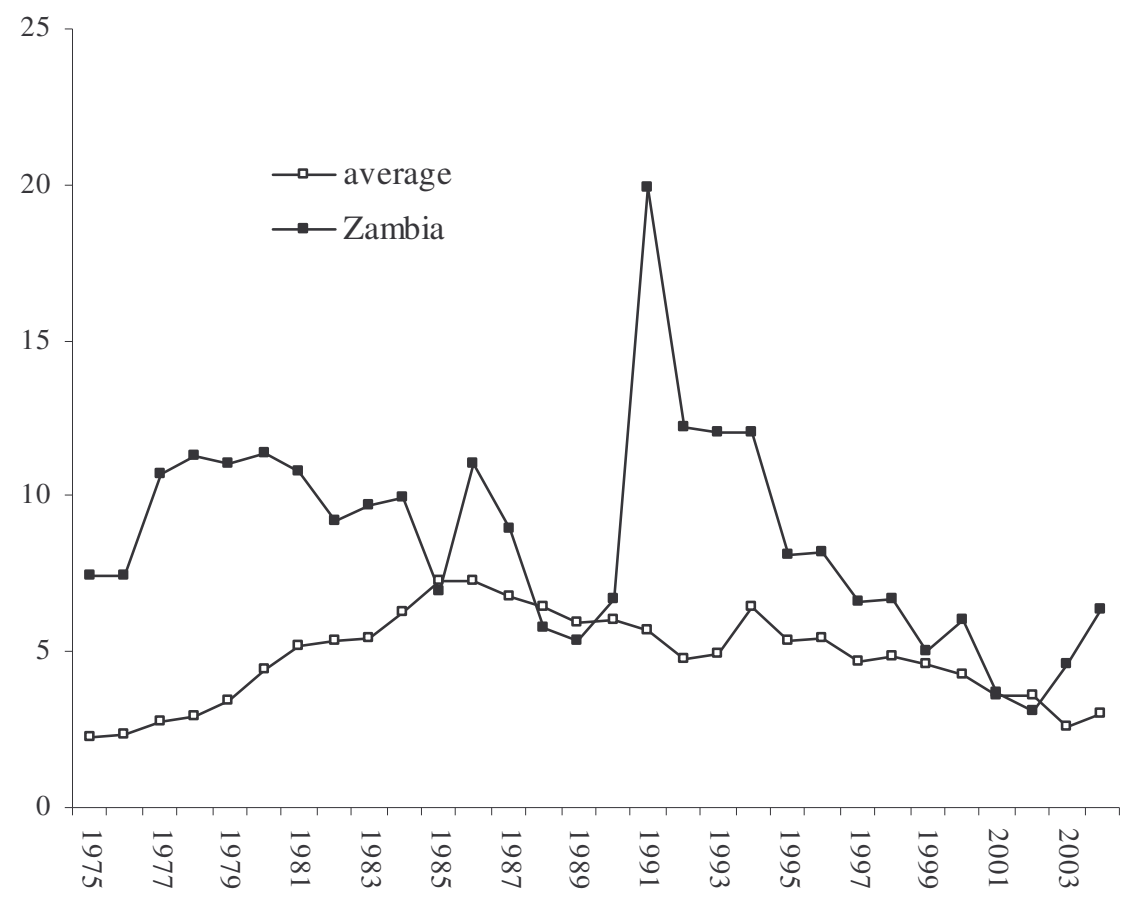

Source: See Figure 1.

FIGURE 3

External Debt per Capita, Zambia and Other Sub-Saharan African Countries, Observed and Adjusted for the Terms of Trade 1975-2004 (current US dollars, 3-year moving average)

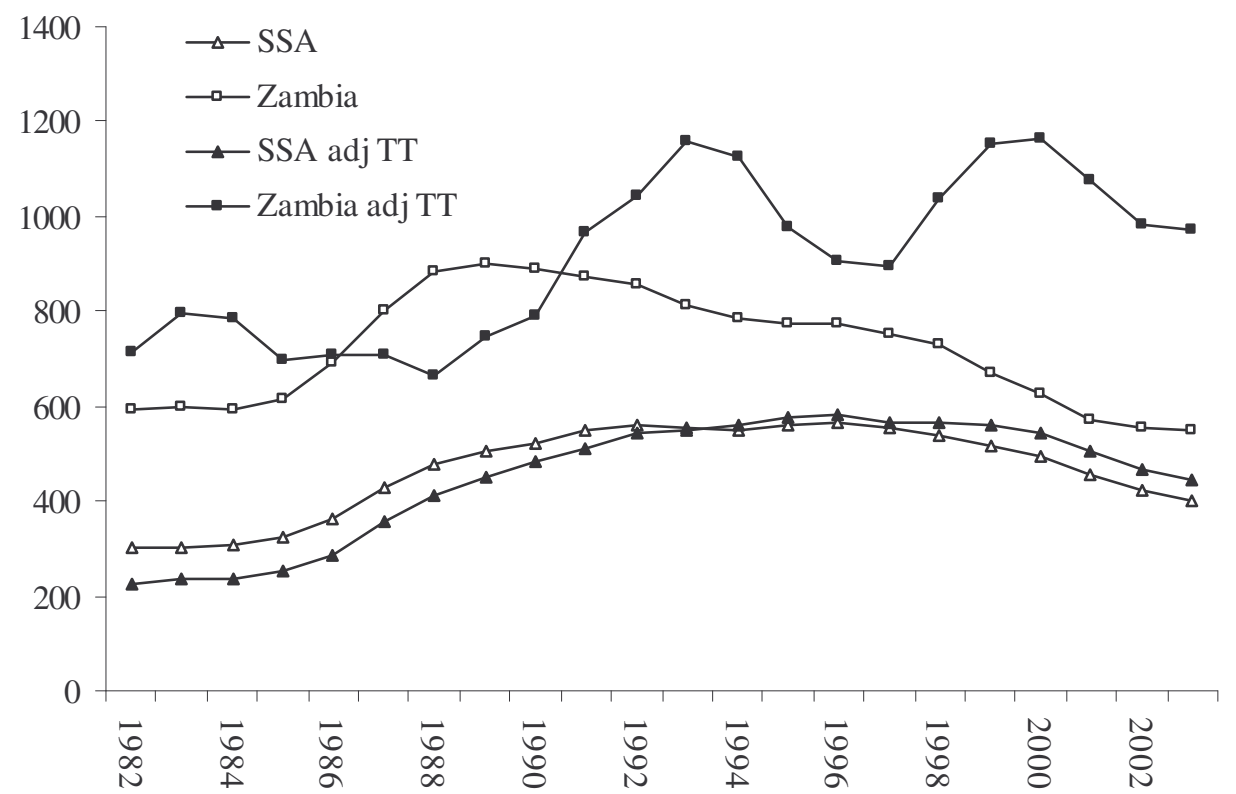

Source: See Figure 1. 
Clearly, external debt was not just one of the problems constraining growth and poverty reduction in Zambia: it was the central problem. Full debt cancellation could, in fact, increase the potential fiscal space for growth-enhancing pro-poor expenditures by almost seven percentage points of GDP.

First, we consider the relief realised by reaching the HIPC completion point. The amount of debt relief under the HIPC initiative derives from what is called a 'sustainability analysis'. This exercise involves a projection of key debt indicators, the most important being the debt-to-export ratio. Thus, central to the amount of debt relief granted is the projection of export growth.

After Zambia reached its decision point in December 2000 (i.e, it qualified for relief), the IMF made a preliminary sustainability analysis. In a 2005 publication, it concluded, 'export growth [during 1999-2003] was considerably slower than projected' (IMF 2005a, 23). Notwithstanding the unrealised optimism of the IMF, the decisive debt sustainability analysis in 2005 presumed 'strong [export] growth over the medium term, reflecting major investments in mining and agriculture' (IMF 2005a, 25).

Perhaps this prediction was made on the basis of the substantial increase in the price of copper in 2004, which was bolstered by even greater increases in 2005 and 2006. While these increases fuelled optimism, the considerable instability of the copper price over the mediumand long-term should have led to greater caution in projections.

There are several reasons that the IMF sustainability analysis was too optimistic. Several of the projections seem dubious compared to the economic record prior to the completion point. The long-term growth rate was predicted to be steady at five per cent per year-but under restrictive fiscal and monetary policies. Under similar policies, the average for 2001-2004 was, in fact, slightly less than this, i.e., 4.7 per cent. But this rate should be viewed as unusually high compared to the performance of the previous decade.

The projected growth rate appeared all the more optimistic since the investment share in GDP was predicted 'to hold steady at 22.5 per cent of GDP, down over 2-3 percentage points from present levels', and foreign investment 'was projected to fall off from its current high'. When combined with the falling investment share, the policy prescription that the public budget not be expansionary placed the entire burden of demand generation for the economy on the optimistic export projection.

Furthermore, the IMF states that inflation, which was below ten per cent in only three of the 40 years during 1965-2004, is 'expected to fall to 5 per cent... by 2007' (IMF 2005a, 25). This exercise does not explain how inflation would be so drastically reduced without contractionary policies that would also reduce growth. The fall in inflation in late 2005 and 2006 was the direct result of a nominal appreciation of the exchange rate of 40 per cent. If such an appreciation continued to be the main deflationary mechanism, however, the cure for inflation would be worse than the disease.

The most important variables for the sustainability exercise are presented in Table 1, which provides the values projected in 2000 when Zambia reached the HIPC decision point. These are accompanied by the actual outcomes, as presented by the IMF (IMF 2005a, Tables 11 and 12). Note that the assumed growth rate for 2000-2004 was not far off the actual outcome. However, the growth rate during those five years was well in excess of any previous five-year period over two decades. Projecting this rate for the next 19 years, 2005-2023, implies that growth conditions would be considerably more favourable than in the past, notwithstanding 
the contractionary impact of a policy focused on inflation reduction. Specifically, it assumes that the real price of copper would remain well above its historical levels.

TABLE 1

HIPC Debt Sustainability Analysis: Assumptions and Outcomes for GDP and Exports, 2000 onwards

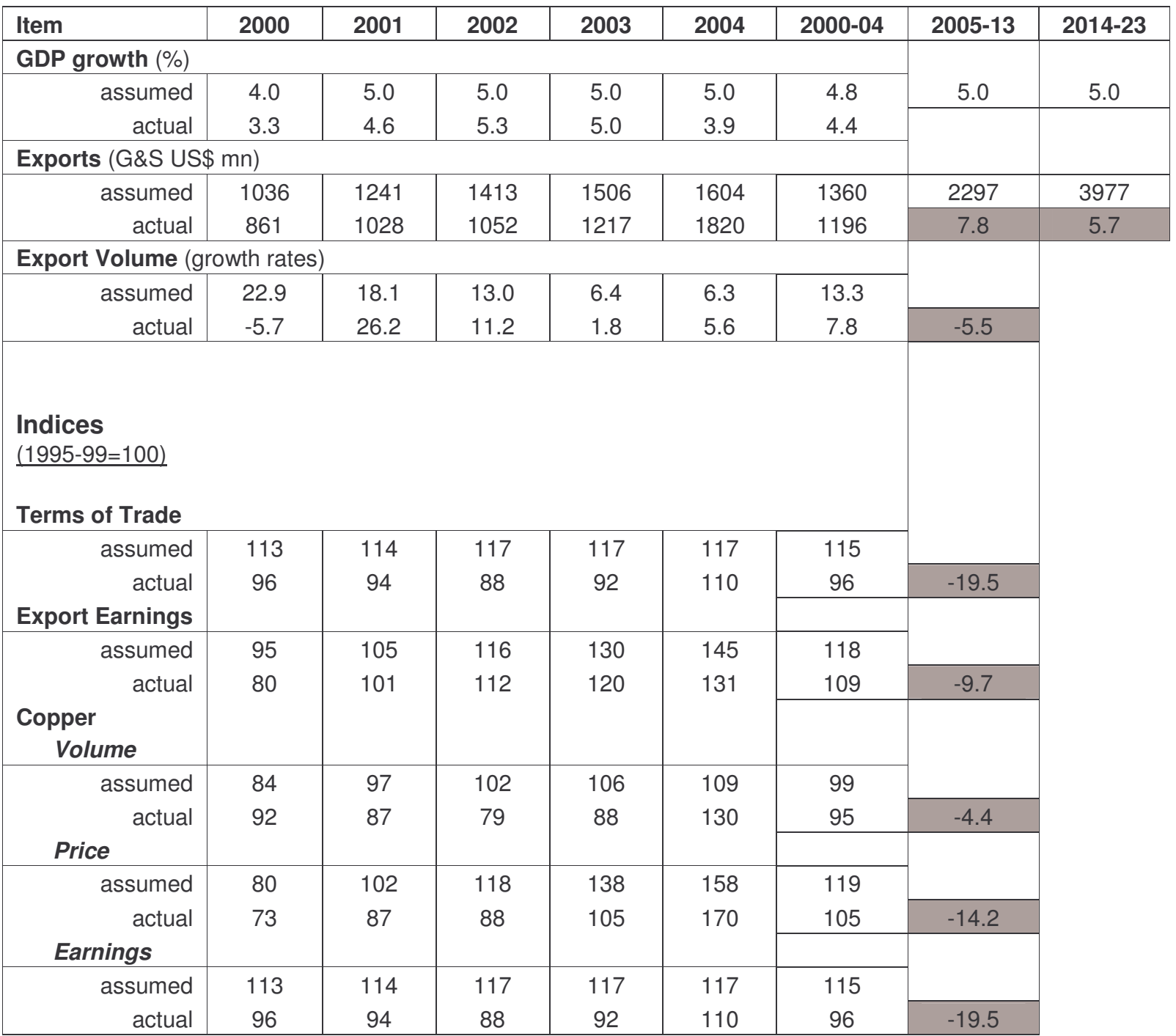

Note: Shaded Cells for Exports G\&S are annual growth rates. The other shaded cells give the percentage point difference between assumed values and outcomes.

Source: IMF (2005a, Tables 11 and 12).

The most serious shortcoming of the assumptions of the sustainability analysis was the underestimation of the instability of copper prices. Greater caution should have been required with regard to projecting the continuation of the high prices of the mid-2000s. The sustainability exercise includes a 'sensitivity analysis' that incorporates the 'shock' of a 20 per cent fall in the copper price. But such a fall would not shock anyone familiar with the international copper market: the coefficient of variation of the copper price during 1995-2004, for instance, was 0.21. This coefficient implies that a fall in the price in excess of 20 per cent could be expected in about one year out of five. 
This high degree of instability in the copper price underscores the most serious danger to debt sustainability and, more fundamentally, the sustainability of Zambia's development: its dependence on copper. A 20 per cent fall or more becomes all the more likely given the extraordinarily high world price in 2006, approaching US\$ 6,000 a ton. Past dependence on copper caused Zambia's debt accumulation; so a return to that dependence is unlikely to be the solution. In the absence of a purposeful plan for export diversification, strongly supported by public investment, copper could again dominate the economy.

Public investment for growth and poverty reduction requires sufficient fiscal space. Therefore, the government must have been disappointed to discover how little space HIPC debt relief created. The IMF completion point document reports that 'HIPC Initiative interim debt relief' amounted annually to a reduction of debt service of 5.7 per cent of GDP during 2001-2005. ${ }^{6}$ However, reduction of the debt service item in the public budget was less than half this, namely, 2.6 percentage points of GDP. And out of the 2.6 percentage points, what were called 'priority poverty reducing programme expenditures' accounted for 1.5 percentage points. The total 3.1 percentage point difference between 'HIPC debt relief' and budget payments represented debt service paid out under another accounting category. To quote from the IMF,

Given that the Bank of Zambia faced large debt service obligations, whose non-payment could have resulted in a curtailment of non-HIPC donor assistance, HIPC interim debt relief accruing to the Bank of

Zambia was designated for debt service payments. The remainder has mostly been allocated to priority poverty-reducing programmes, which focused on investments in infrastructure, support for small-scale farmers and food security, and increased expenditures in the social sectors, in particular, education. (IMF 2005a, 19).

In other words, over half of HIPC interim debt relief (3.1 out of 5.7 percentage points) was merely an accounting entry. Furthermore, to write that the 'remainder was mostly allocated' to poverty reduction programmes involves loose usage of the word 'mostly', since less than 60 per cent of the 2.6 percentage points of actual debt service reduction went to this item. Whether the promise by the G-8 heads of state in July 2005 to completely cancel all IMF and World Bank debts to HIPC countries reaching completion point would bring more effective debt relief to Zambia than the HIPC initiative is considered below.

In the following section, this Country Study demonstrates that far from increasing fiscal space, the overall effect of HIPC debt relief would slightly reduce it, primarily as a result of macroeconomic conditionalities. Furthermore, it shows that full implementation of the G-8 debt cancellation would increase fiscal space, but, because of remaining binding policy conditionalities, by less than one percentage point of GDP. Thus, the constraining role of these conditionalities should be subject to re-evaluation within the context of the poverty reduction strategy process.

\section{THE EFFECT OF DONORSHIP ON NATIONAL BUDGETING7}

The constraining burden of Zambia's debt for three decades has been closely related to conditionalities set by external agencies. In other words, Zambia's governments have had very little 'policy space'. Indeed, so numerous and specific have been the conditionalities that once 
they have been accepted by Zambian governments, very little discretion has remained for the important decisions affecting economic management. In other words, the conditionalities, restrictive in themselves, constrained other policies not explicitly subject to conditionality. ${ }^{8}$

Tables 2 and 3 indicate the extent to which the multilateral agencies have influenced policy in Zambia. The former lists the major interventions and the latter some of the more important conditionalities. The tables demonstrate clearly that from the late 1980s, conditionalities directly constrained the government's actions in almost every important area of economic policy and, in some cases, social policy. Table 2 also reveals the extremely troubled interaction between the multilateral agencies and Zambia's governments. Examine the instances of the cancellation or suspension of programmes, which are shaded.

TABLE 2

IMF and World Bank Operations in Zambia, 1973-2005

\begin{tabular}{|c|c|c|}
\hline Date & IMF & World Bank \\
\hline 1973 & one year standby agreement & Programme loan for 1973 oil price shock \\
\hline 1976 & one year standby agreement & $\begin{array}{l}\text { Programme loan in response to fall in copper } \\
\text { prices }\end{array}$ \\
\hline 1978 & two year standby agreement & $\begin{array}{l}\text { First IDA credit (previously Zambia was a } \\
\text { middle-income country by WB measures) }\end{array}$ \\
\hline 1981 & three year Extended Fund Facility & \\
\hline 1982 & Extended Fund Facility cancelled & \\
\hline 1983 & one year standby at end of year & $\begin{array}{l}\text { WB suspends disbursements due to } \\
\text { government non-payment of external debts; } \\
\text { negotiations resume at end of year }\end{array}$ \\
\hline 1984 & 21 month standby agreement & Project loan for copper sector \\
\hline 1985 & Standby suspended & $\begin{array}{l}\text { Policy package agreed with the WB, resulting } \\
\text { in first Structural Adjustment loan }\end{array}$ \\
\hline 1987 & Government cancels IMF programme & Government cancels WB programme \\
\hline $1989-1990$ & Preliminary agreement for new lending & Preliminary agreement for new lending \\
\hline 1991 & Lending agreement suspended by IMF & Lending agreement suspended by WB \\
\hline 1992 & $\begin{array}{l}\text { agreement reached allowing access to IMF loans } \\
\text { despite arrears }\end{array}$ & arrears to WB cleared \\
\hline 1995 & $\begin{array}{l}\text { three year Enhanced Structural Adjustment } \\
\text { Facility (ESAF), one year Structural Adjustment } \\
\text { Facility (SAF), with total of US } \$ 1,300 \text { million }\end{array}$ & $\begin{array}{l}\text { Economic Recovery \& Investment Project } \\
\text { (ERIP) agreed, with sectoral programmes } \\
\text { resulting }\end{array}$ \\
\hline 1999 & 3 year ESAF (US\$ 350 million) & Sectoral \& Project loans \\
\hline 2000 & $\begin{array}{l}\text { IPRSP positively reviewed by joint IMF/WB board; } \\
\text { in December HIPC decision point reached }\end{array}$ & Sectoral \& Project loans \\
\hline 2002 & $\begin{array}{l}\text { PRSP positively reviewed by joint IMF/WB board, } \\
\text { but HIPC process delayed over bank privatisation }\end{array}$ & Sectoral \& Project loans \\
\hline 2004 & $\begin{array}{l}\text { Poverty Reduction \& Growth Facility loan (PRGF) } \\
\text { of US\$ } 320 \text { million }\end{array}$ & Sectoral \& Project loans \\
\hline 2005 & $\begin{array}{l}\text { HIPC completion point reached in April, after over } \\
\text { four years }\end{array}$ & Sectoral \& Project loans \\
\hline
\end{tabular}

Source: Situmbeko and Zulu (2004), up-dated from WB and IMF websites.

The major role played by policy conditionalities in Zambia has been inconsistent with the Poverty Reduction Strategy Paper (PRSP) process. Official World Bank documents stress that a fundamental change in its lending approach was the adoption of the principle of recipient ownership of policy making (Klugman 2002). However, this change in approach has remained unrealised in Zambia in the 2000s. 
The presumptions about national owernship have tended to guide donors and lenders in their relations with Zambia from the late 1980s onwards. However, a major donor criticism of recipient governments is that while they might be aware of the needed policy reforms, and aware of the need to implement them, they fail to so because of special interests within or outside of the government. In such circumstances, the argument goes, donors are justified in their criticism of policy choices and, moreover, the criticism might strengthen domestic supporters of the supposedly sound policies.

This argument strengthens the tradition of donorship because it implicitly suggests that institutional, political, and economic interests do not also motivate donors. This approach is increasingly unacceptable in the twenty-first century. Following PRSP guidelines, the development strategy of every country should be established through a democratic process. Such a process has functioned relatively well in Zambia since the 1980s.

TABLE 3

Some IMF \& World Bank Conditionalities for Zambia, 1991-2005

\begin{tabular}{|c|c|c|}
\hline Date & IFI & Details \\
\hline 1991 & World Bank & $\begin{array}{l}\text { Economic Reform Credit: } \\
\text { deregulate maize markets, limit bank credits, remove tariff bans, reduce civil } \\
\text { service employment, initiate privatisation }\end{array}$ \\
\hline 1992 & World Bank & $\begin{array}{l}\text { Privatisation and Industrial Reform Credit (PIRC I): } \\
\text { harmonise sales taxes, broaden tax base, reduce tariffs, reduce public } \\
\text { employment by ten thousand, pass privatisation law, restructure state mining } \\
\text { company }\end{array}$ \\
\hline 1992 & IMF & $\begin{array}{l}\text { Rights Accumulation Programme: } \\
\text { pay arrears to international creditors }\end{array}$ \\
\hline 1993 & World Bank & $\begin{array}{l}\text { PIRC II: } \\
\text { reduce tariffs, develop land market, change investment act, privatise } 60 \\
\text { companies including state copper corporation }\end{array}$ \\
\hline 1994 & World Bank & $\begin{array}{l}\text { Economic \& Structural Adjustment Credit (ESAC I) } \\
\text { redirect budget funds to social sectors, eliminate export ban on maize, create } \\
\text { legal framework for land leasehold, sell public owned farms, develop financial plan } \\
\text { for Zambia Airways }\end{array}$ \\
\hline 1995 & World Bank & $\begin{array}{l}\text { Economic Recovery\& Investment Project (ERIP): } \\
\text { introduce value added tax, institute minimum budget and spending targets for } \\
\text { social services, change social security system, privatise state copper corporation }\end{array}$ \\
\hline 1995 & IMF & $\begin{array}{l}\text { Enhanced Structural Adjustment Facility (ESAF): } \\
\text { Introduce quantitative benchmarks including increased domestic assets of BOZ, } \\
\text { increase foreign reserves, reduce government domestic debt arrears, restructure } \\
\text { civil service, publish banking regulations, privatise state copper corporation }\end{array}$ \\
\hline 1996 & World Bank & $\begin{array}{l}\text { ESAC II: } \\
\text { mandate social sector funding at least } 35 \% \text { of total public budget, implement } 1995 \\
\text { land act, amend employment \& industrial labour relations act, formulate policy for } \\
\text { NGOs to deliver social services }\end{array}$ \\
\hline 1999 & World Bank & $\begin{array}{l}\text { Structural Adjustment Fund: } \\
\text { reform civil service, publish banking regulations, privatise state copper corporation }\end{array}$ \\
\hline 1999 & IMF & $\begin{array}{l}\text { ESAF: } \\
\text { privatise state enterprises including ZCCM, telecommunications, electricity } \\
\text { \& post office; insist on no intervention in exchange rate market; deregulate } \\
\text { strategic grain reserve; end public distribution of fertiliser; implement restrictive } \\
\text { monetary \& fiscal policy }\end{array}$ \\
\hline 2000 & $\begin{array}{l}\text { IMF \& } \\
\text { World Bank }\end{array}$ & $\begin{array}{l}\text { HIPC decision point: } \\
\text { complete privatisation of public enterprises }\end{array}$ \\
\hline 2001 & IMF & $\begin{array}{l}\text { PRGF: } \\
\text { privatise ZNCB \& ZESCO, deregulate \& privatise energy sector and ZNOC; insist } \\
\text { on no intervention in exchange rate market; limit government expenditure }\end{array}$ \\
\hline
\end{tabular}

Source: Situmbeko and Zulu (2004), up-dated from WB and IMF websites. 
The HIPC debt reduction process has been very much a part of the donorship approach. Qualifying for debt relief by reaching the 'decision point' has explicitly required faithful adherence, over several years, to IMF and World Bank programmes that have been characterised by detailed conditionalities (see Table 3). The considerable delay in Zambia's debt relief, i.e., reaching the 'completion point', resulted from the insufficient progress made by the government on one specific conditionality, namely, privatisation of the Zambian National Commercial Bank (see discussion in Situmbeko \& Zulu 2004, 42ff).

In no areas of policy have the constraints of conditionalities been more restrictive than in fiscal policy. After 1990, direct fiscal conditionalities included 1) deficit limits, 2) a cap on the share of public-sector wages in GDP, and 3) reliance on 'cash budgeting'. The last, which has limited budget expenditures to each ministry's own current cash balance, has impeded policy implementation. The cash balance limit is especially dysfunctional and irrational for capital projects, whose expenditure requirements are often 'front-loaded'. Such budgeting has led to numerous interruptions in the construction of infrastructure and has often resulted in abandoning projects in process. ${ }^{9}$

\section{DEBT REDUCTION AND FISCAL SPACE}

The fundamental purpose of the HIPC process and the G-8 debt cancellation was to create fiscal space for poverty reduction expenditures. Poverty Reduction Strategy Papers were created in the 1990s as part of this process. Only later did they become more general in purpose, serving as the basis for donor and lender support and for linking poverty reduction strategies to the MDGs.

If debt relief fails to increase space for poverty-reduction expenditures, it has failed, in fact, in its fundamental purpose. A close inspection of the official IMF projection of revenue and expenditure in the five years immediately following Zambia's attainment in 2005 of the 'decision point' yields a startling conclusion: as a ratio to GDP, HIPC debt relief will slightly reduce the amount of expenditure available for poverty reduction programmes, and the G-8 cancellation will increase it only marginally.

During 2000-2004, the Zambian government paid seven per cent of GDP as debt service. The IMF debt sustainability exercise, described above, projected that this would fall to 1.7 per cent during 2006-2010 (see Table 4, data columns 2 and 3). ${ }^{10}$ Someone unfamiliar with the HIPC process might conclude that the fall from seven to 1.7 per cent would release the difference between the two, i.e., 5.3 per cent of GDP, for expenditure at the discretion of the government. If this were the case, the prospects for sustainable growth with poverty reduction would be dramatically improved in Zambia. The IMF projection that taxes and other revenue sources would generate a slightly larger share of GDP (namely, the share would rise from 18.8 to 19 per cent) would be further cause for optimism.

Regrettably, such optimism would be misplaced. First, the IMF exercise anticipated that grants and the grant component of loans, which were 6.5 per cent of GDP during 2000-2004, would fall to 3.5 per cent (see notes to Table 4), ${ }^{11}$ though such a decline would seem to contradict a fundamental commitment associated with HIPC debt relief-namely, that debt relief would not substitute for ODA. ${ }^{12}$ 
TABLE 4

Public Budget, Actual (2000-04) \& IMF Projected (2006-10)

(Percentage of GDP)

\begin{tabular}{|c|c|c|c|c|c|}
\hline \multirow{2}{*}{ Fiscal categories } & \multirow{2}{*}{$\begin{array}{c}\text { Actual } \\
2000-04\end{array}$} & \multirow{2}{*}{$\begin{array}{c}\text { HIPC } \\
2006-10\end{array}$} & \multirow{2}{*}{$\begin{array}{c}\text { HIPC\&G8 } \\
2006-10\end{array}$} & \multicolumn{2}{|c|}{ Change: } \\
\hline & & & & HIPC & HIPC\&G8 \\
\hline Total income & 25.3 & 22.5 & 22.5 & -2.8 & -2.8 \\
\hline Revenue & 18.8 & 19.0 & 19.0 & 0.2 & 0.2 \\
\hline Grants & 6.5 & 3.5 & 3.5 & -3.0 & -3.0 \\
\hline Total expenditure & 29.2 & 23.1 & 23.1 & -6.1 & -6.1 \\
\hline Non-external debt & 22.2 & 21.4 & 23.0 & -0.8 & 0.8 \\
\hline External debt & 7.0 & 1.7 & 0.1 & -5.3 & -6.9 \\
\hline Overall Deficit & -3.9 & -0.6 & -0.6 & -3.3 & -3.3 \\
\hline Fiscal space & & & & -0.8 & 0.8 \\
\hline
\end{tabular}

Notes and Sources: The averages for 2000-04 are from the Ministry of Finance and are the same as given in IMF reports. For 2006-10, revenue and grants are from IMF (2005a) Table 12, and debt service from Table 15. ${ }^{13}$

The decline in grants of 3.0 percentage points reduces the net gain in external flows from 5.3 to 2.3 percentage points. For practical purposes, total expenditure less external grants for 2006-2010 was mandated not to exceed total revenue by more than one per cent of GDP. With the added condition that domestic borrowing be limited to 0.6 per cent of GDP (implying that 0.4 percent points would be covered by external grants), the net reduction in the fiscal deficit would be 3.3 per cent of GDP (from -3.9 to - 0.6 per cent).

Since the increase in revenue would add 0.2 percentage points to the 2.3 per cent due to ODA, this tracking of percentages and fractions thereof yields the conclusion that in the first five years after the HIPC decision point, assuming other public expenditure obligations were not reduced, the change in fiscal space for poverty expenditure would be minus $\mathbf{0 . 8}$ per cent of GDP (2.5 - 3.3 per cent).

This unexpected result can be summarised as follows: 1) other factors remaining unchanged, HIPC debt relief would increase fiscal space by 5.3 percentage points of GDP; 2 ) the expected increase in government revenue would add another 0.2 percentage points; 3 ) accounting entries and reduction in grants by 3.0 percentage points would reduce the fiscal gain to 2.5 per cent of GDP ( 5.5 - 3.0); and 4) a tighter deficit limit (of -0.6 versus -3.9) would reduce it further to minus 0.8 per cent $(2.5-3.3)$.

If, as the government anticipated in 2006, the G-8 cancellation of IMF and World Bank debts were realised, the result from debt relief would improve, but only marginally (MFND $2006,3)$. The further reduction of debt service, from 1.7 to 0.1 per cent of GDP would add a small fiscal space of $\mathbf{0 . 8}$ percentage points. Even before undertaking a detailed analysis of the cost of achieving the MDGs in Zambia, it should be obvious that this marginal increase in fiscal space would be woefully inadequate.

\section{CREATING FISCAL SPACE FOR THE MDGS ${ }^{14}$}

Though it has produced an extremely small poverty expenditure 'dividend', the HIPC and G-8 processes have certainly not been pointless. They have dramatically reduced Zambia's external debt and the servicing associated with it. In the long run, this should contribute to sustained 
growth, though the cost (e.g., the associated distortions of the policy priorities and human resource inputs of the government) could be high. Higher levels of non-debt Official Development Assistance would be welcome, but in mid-2006 there was no prospect of such an increase. Moreover, the IMF has projected a decline.

TABLE 5

Government Expenditures in 2005 and the MDG 'Gap'

\begin{tabular}{|c|c|c|c|c|c|}
\hline \multirow[b]{2}{*}{ Expenditure items } & \multirow{2}{*}{$\begin{array}{c}2005 \\
\text { Actual }^{\star}\end{array}$} & \multicolumn{2}{|c|}{ Percent of: } & \multicolumn{2}{|c|}{ Percent of GDP } \\
\hline & & $\begin{array}{l}\text { Domestic } \\
\text { budget }\end{array}$ & GDP & MDG cost & MDG gap \\
\hline Economic sectors & 1023.6 & 17.0 & 3.1 & & \\
\hline Agriculture & 346.4 & 5.8 & 1.1 & & \\
\hline Mining & 16.4 & 0.3 & 0.1 & & \\
\hline Tourism & 40.8 & 0.7 & 0.1 & & \\
\hline Communications/transport & 437.4 & 7.3 & 1.3 & 3.0 & -1.7 \\
\hline Energy & 22.3 & 0.4 & 0.1 & 2.0 & -1.9 \\
\hline Construction & 82.4 & 1.4 & 0.3 & 3.0 & -2.7 \\
\hline Commerce & 42.0 & 0.7 & 0.1 & & \\
\hline Environment & 20.2 & 0.3 & 0.1 & & \\
\hline Other & 15.7 & 0.3 & 0.0 & & \\
\hline Social sectors & 1763.9 & 29.3 & 5.4 & & \\
\hline Education & 1062.8 & 17.6 & 3.3 & 3.0 & 0.3 \\
\hline Health & 480.0 & 8.0 & 1.5 & 7.0 & -5.5 \\
\hline Water \& sanitation & 32.4 & 0.5 & 0.1 & 2.0 & -1.9 \\
\hline Social Safety nets & 89.7 & 1.5 & 0.3 & 3.0 & -2.7 \\
\hline Disaster relief & 52.3 & 0.9 & 0.2 & & \\
\hline Other & 46.7 & 0.8 & 0.1 & 1.0 & -0.9 \\
\hline Other expenditures & 3235.1 & 53.7 & 9.9 & Total: & Total: \\
\hline Total domestic budget & 6022.6 & & 18.4 & 24.0 & 17.1 \\
\hline Total expenditure & 6621.3 & & 20.3 & & \\
\hline $\begin{array}{l}\text { Foreign financed } \\
\text { Capital Expenditure }\end{array}$ & 2224.5 & & 6.8 & & \\
\hline Total budget & & & 27.1 & & \\
\hline
\end{tabular}

If Zambia will achieve sustained poverty-reducing growth and attain the MDGs, the fiscal space that HIPC and the G-8 have failed to provide must be created through other means. The protracted HIPC process carried an important lesson: present and future governments of Zambia must seek to mobilize additional domestic resources for generating growth and achieving poverty reduction. ${ }^{16}$ They should not rely on either debt relief or additional ODA

To consider the scale of the task needed to finance the achievement of the MDGs, we begin with the fiscal allocations for 2005, shown in the first data column of Table 5 . The second column gives each item as the percentage of the domestic budget, and the third column as the percentage of GDP. The fourth column reports the estimated expenditure share of GDP necessary to achieve the MDGs (Mphuka 2005; also see notes to Table 5). The summation of the fourth column amounts to almost a quarter of GDP (i.e., 24 per cent), larger than the domestic budget (i.e., 20.3 per cent, which is expenditure minus external debt service). 
The calculations below make the strong assumption that the expenditures in budget items that correspond to the MDG categories all contribute to attaining the MDGs (see MFND $2006,6)$. For example, it is assumed that the funds for education are all MDG fostering. On this assumption, the net increase in expenditure necessary to reach the MDGs sums to $17.1 \mathrm{per}$ cent of GDP (the sum of the 'MDG gaps', the last cell of the last column).

TABLE 6

Proposal for the Financing to Achieve the MDGs in 2015*

\begin{tabular}{|l|c|c|}
\hline & \% of GDP & Addition to budget \\
\hline MDG deficit & -17.1 & 0.0 \\
Financed by: & & 0.0 \\
1. Reducing external debt service & 1.2 & 3.0 \\
2. Restructuring domestic debt & 3.0 & 0.0 \\
3. Increasing tax revenue & 3.3 & $\mathbf{2 . 4}$ \\
4. Shifting 'other' expenditures & 2.4 & 0.0 \\
5. Increasing the fiscal deficit & 3.4 & 3.4 \\
6. Foreign financed capital spending & 3.4 & $\mathbf{8 . 8}$ \\
7. Increasing ODA grants & & 27.1 \\
Sum & 17.1 & 35.9 \\
\hline Total expenditure 2005 & & \\
\hline Total Expenditure, with MDGs met & & \\
\hline
\end{tabular}

Notes: *All estimates are averages for 2006-2015.

Source: See previous table.

1. Reduction of external debt service: assuming full G8 cancellation and bilateral cancellation.

2. Restructure domestic debt: new government bonds replace domestic debt at a 50 per cent discount.

3. Increased corporate tax, with most revenue coming from mining.

4. Reallocation of one-third of the total from 'General Public Services, Defense and Public Safety'.

5. Fiscal deficit (public borrowing) rises to three per cent of GDP.

6. Budget item 'Foreign financed' capital expenditures, which is not included in Table 4.

7. Increase in external grants (residual item to fully cover the MDG gap).

Having estimated the fiscal effort required (which appears substantial), we move to Table 6, which provides a proposal for funding the 'MDG gap'. The first two sources of funding (items $\# 1$ and \#2) come from reducing government interest payments. External interest payments, which were 0.4 per cent of GDP in 2005, would fall to 0.1 per cent after realisation of the G-8 debt cancellation. This would free up 0.3 per cent of GDP in fiscal space (column 1). Item 2 presumes a restructuring of the domestic debt by issuing new government bonds to replace domestic debt at a fifty per cent discount. This would free up 1.2 per cent of GDP in financing (column 1).

\section{RAISING MORE TAX REVENUE}

The third source of funding calls for an increase in tax revenue of three percentage points of GDP. Figure 4 shows that during 1990-2004 taxes accounted for the overwhelming proportion of revenue, with fees and other sources making a minor contribution. In most cases, it would be regressive to increase non-tax revenue, such as introducing 'user fees' for health, education and basic utilities (Weeks et. al. 2006, Chapter 7). Figure 5 shows that four major types of taxes account for almost all of tax revenue in Zambia. In contrast to the structure in almost every 
other sub-Saharan African country, personal income taxes have generated the largest share of revenue in Zambia. Raising the rates for the highest income earners would bring a small increase in revenue. But we propose that the best use of this additional revenue would be to reduce rates on the poorest income tax payers (see Weeks, et. al. 2006, Chapter 3).

FIGURE 4

External Grants, Revenue and Taxes as Percentage of GDP, 1990-2004

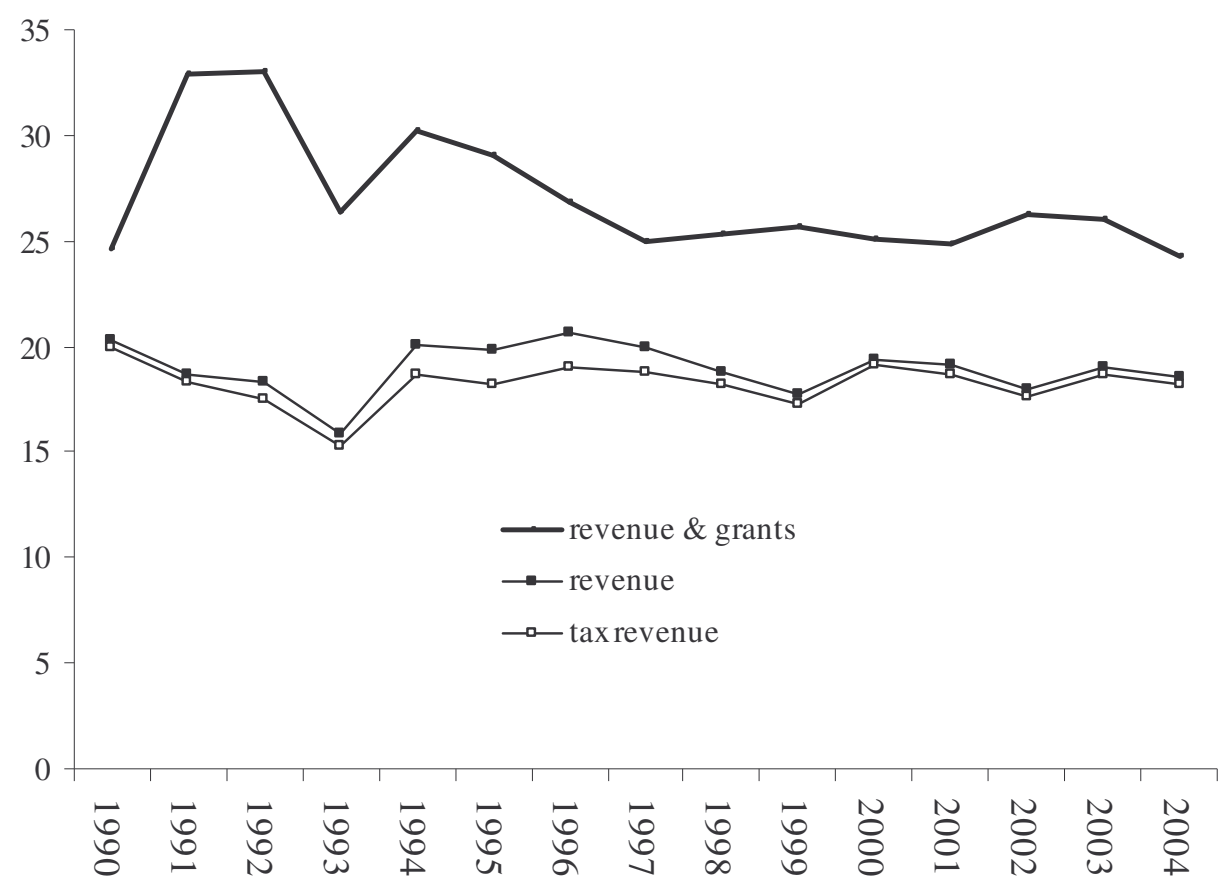

Source: Ministry of Finance and National Planning, Macroeconomic Indicators (1997-2005).

Note: Difference between taxes and revenue in 2000 was almost entirely proceeds from the privatisation of ZESCO.

Despite the tariff reductions during the 1990s, trade taxes have held remarkably steady in their contribution to revenue. WTO restrictions on tariff increases allow limited scope for increasing revenue from this source. ${ }^{17}$ The value added tax (VAT) has generated relatively little revenue despite claims about its effectiveness. Moreover, its expansion, were it indeed effective in collecting revenue, would be regressive.

There could be considerable scope for increasing the corporate tax, which in 1990 brought in over six per cent of total tax income. Trade liberalisation and the decline of copper have reduced its contribution dramatically. However, the rejuvenation of the copper sector and the growth of agribusiness provide ample scope for expanding this tax base, especially if various forms of tax exemptions were removed.

Zambia's earlier legal commitment to an ill-conceived tax holiday arrangement with the copper companies should not pose an insurmountable obstacle to re-imposing levies on the sector. One can find many international examples of the alteration of tax rules by government when circumstances change significantly. The dramatic increase in the copper price since privatisation and the subsequent questionable behaviour of some of the copper companies combine to justify a change in government policy. ${ }^{18}$ Since the world market for copper is experiencing excess demand, a change in policy would be unlikely to deter production or even new investment. 
FIGURE 5

Types of Taxes as a Percentage of GDP, 1990-2004

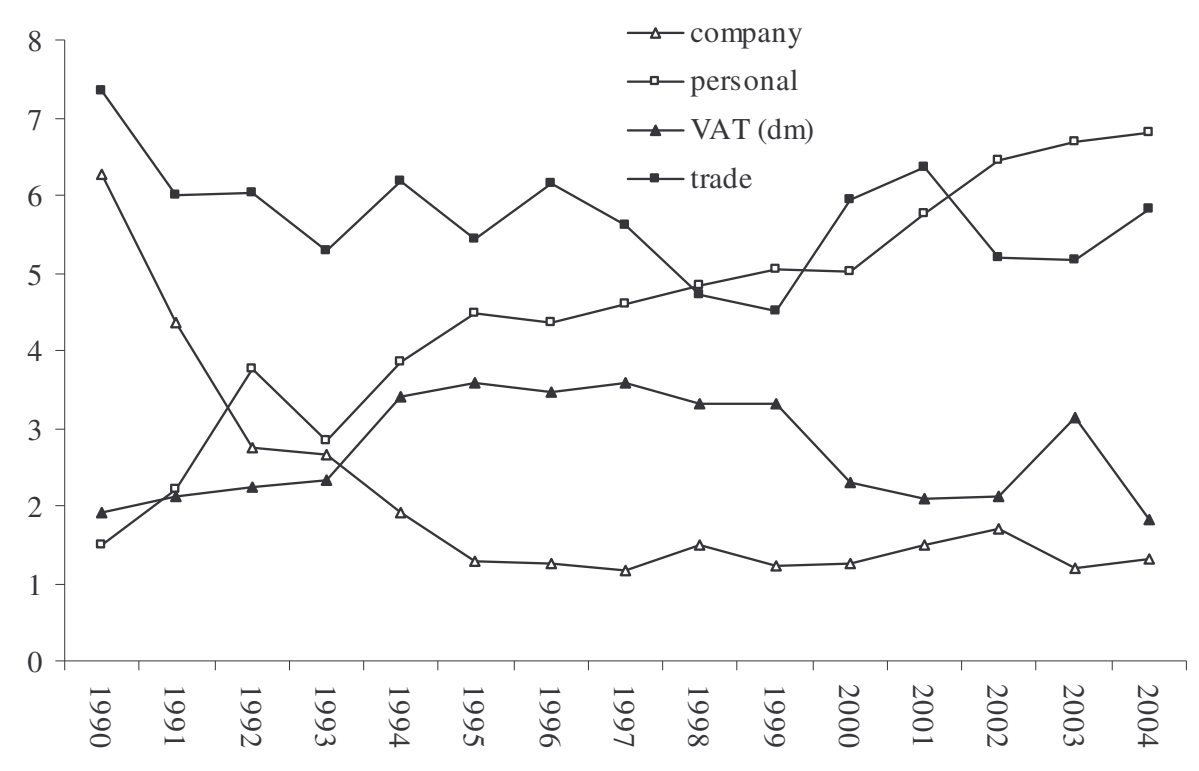

Source: See Figure 1.

The fourth funding source in Table 6 assumes that one third of 'Other Expenditures' (totalling 9.9 per cent of GDP, (see Table 5, column 3)) could be shifted to MDG expenditures. Some of this shift might involve no more than re-labelling because the cost of implementing MDG expenditures would fall under general government operations. However, the majority of the shift would require re-assigning civil servants to new activities, which could have costs associated with training and related activities.

\section{INCREASING DOMESTIC BORROWING}

The fifth funding source assumes an increase in domestic borrowing. But this would be viable only if the current domestic debt were restructured. The full Zambia report (Weeks et al. 2006, Chapter 6) provides several recommendations on how to stabilize and restructure the domestic debt. The government needs a clear strategy to deal with major issues such as clearing arrears and addressing pension liabilities. A welcome initial action to deal with debt would be to reduce interest rates on government securities. This would also have beneficial effects economy-wide. An additional helpful measure would be the introduction of long-term (ten- to twenty-year) government bonds (i.e., thereby lengthening the maturities of securities).

An option designed to deal directly with current debt is to convert outstanding shortterm T-bills and bonds into index-linked instruments bearing lower interest rates and longer maturities and allowing banks to use these securities as part of their compulsory reserves. This Country Study recommends specifically that the government issue new long-term bonds that would replace existing short-term T-bills and bonds but carry out this conversion on the basis of a fifty per cent discount in value.

The domestic borrowing level for 2006-2010, to which the government agreed as part of the HIPC process, is restricted to less than one per cent of GDP. But this has little economic justification. Once the domestic debt is restructured to be sustainable, such a small deficit 
would be below the optimum level. Accumulating domestic debt at the yearly rate of 0.6 per cent of GDP would imply, in fact, a rapidly declining debt to GDP ratio if the economy grew at the IMF projected rate of five per cent per annum.

We propose to increase the deficit to 3.0 per cent of GDP (an additional 2.4 percentage points). However, some conservative economists might be concerned that such an increase in financing would accelerate inflation. But the Quantity Theory of Money suggests that for a typical value of the velocity of money, the inflationary impact would be small, even if such a deficit were monetised. If the deficit were covered, instead, by domestic borrowing, it would have no direct inflationary effect because the net impact on the money supply would be zero.

The other possible impact of a higher deficit would be upward pressure on commercial interest rates. This is shown to be unlikely in the full Zambia report (see Weeks et. al. 2006, Chapter 6). If the 'crowding out' effect of higher interest rates were operative, it would be demand reducing for the private sector through its impact on investment although it would not be inflationary. However, since the increase in the deficit could be used for public investment, the net effect on aggregate investment, private and public, could be growthenhancing. The capital expenditure required for the achievement of the MDGs would bring public investment, for instance, to well above three per cent of GDP.

It is contrary to economic theory, as well as common sense, to fund investment out of current income, since investment projects generate a future flow of income that can finance themselves (that is why there are capital markets). The reason that the government might not fully fund investment by borrowing is the possible inflationary effect. But this possibility has been discounted above. Thus, there would be no compelling economic argument against expanding fiscal space, through domestic borrowing, to three per cent of GDP_namely, in excess of the extremely low current 'cap' of 0.6 per cent of GDP.

Item 6, 'foreign financed capital expenditure', which is not part of the domestic budget, was 3.4 per cent of GDP in 2005. The calculations assume that all of this would contribute to achieving the MDGs during 2006-2015. This assumption is realistic if concessional lending is aligned, as it should be, with MDG objectives.

Finally, an increase in ODA grants (item \#7) serves as the residual item to fill the MDG gap. The assumed increase in ODA grants in Table 6, i.e., 3.4 percentage points, is less than the 4.5 per cent of GDP programmed by the government in its draft National Development Plan. Thus, our financing proposal assumes less reliance on ODA.

The percentages for MDG expenditures in Tables 5 and 6 were calculated on the assumption of a growth in per capita income of 2.2 per cent per annum (Mphuka 2005). According to World Bank data, Zambia's population growth was 1.4 per cent in 2004. On the assumption that population would expand at the slightly higher rate of 1.5 per cent during 2006-1015, a per capita growth rate of 2.2 per cent would imply GDP growth of 3.7 per cent.

At this rate of growth, the seven financing items would need to cover an increase in government expenditures of $\mathbf{8 . 8}$ percentage points. Thus, the share of public expenditures in GDP would rise from 27.1 to 35.9 per cent. Items \#1 and \#2, which reduce the external and domestic debt, respectively, do not imply increased expenditures. The same applies to item \#4, shifting expenditures equivalent to 3.3 per cent of GDP to MDG targets. Also, item \# 6, foreign financing of capital expenditures, does not immediately imply more expenditures in the national budget. 
While the above results are based on assuming a growth rate of GDP per person of 3.7 per cent, if economic growth were more rapid, such as five or seven per cent, the required increase in budget expenditures would decrease. A seven per cent rate of growth maintained over 10 years would double income per person, which would be necessary to halve the proportion of the extremely poor in Zambia. Of course, this assumes that growth is distribution neutralnamely, that inequality neither rises nor falls.

If the growth rate reached the recommended rate of seven per cent per annum over ten years, the increase in government expenditures would be reduced to 7.5 percentage points of GDP and the share of total government expenditures in GDP to 34.6 per cent. This decline in required expenditures results from specifying the expenditures necessary to reach the MDGs in constant prices per person (see Mphuka 2005). As the growth of per capita income increases, the constant MDG expenditure per person declines relative to per capita GDP. ${ }^{19}$

Our projections of additional government expenditures needed to reach the MDGs error on the side of assuming larger expenditures and smaller revenue than are likely. If economic growth per capita would indeed accelerate to seven per cent per annum and remain at that level, public revenues as a share of GDP would likely rise (assuming, of course, that the tax structure is buoyant). In addition, the public expenditures necessary to reach the MDGs would likely fall since a positive income effect would enhance the achievement of several MDGs other than MDG \#1, such as reducing mortality rates or boosting enrolment ratios in schools.

Moreover, if economic growth were not only more rapid but also pro-poor, i.e., benefited poor households disproportionately, then the reduction of extreme income poverty would be more dramatic and, correspondingly, the attainment of various non-income MDG targets affected by growth would be made easier (see Dagdeviren, van der Hoeven and Weeks 2002).

A ten-year growth rate of seven per cent is feasible for Zambia under the scenario of full funding of the MDGs. The increased government expenditure would provide the necessary demand stimulus even if export growth slowed. Supply constraints would be progressively relieved by the MDG public investment programme. However, there would be little prospect for seven per cent growth, or even five per cent, if the IMF-proposed restrictive deficit target of 0.6 per cent of GDP were maintained and monetary policy pursued the IMF-recommended inflation rate of five per cent.

\section{THE MACRO FRAMEWORK FOR THE MDGS}

For the MDG commitment to be more than a slogan, it is necessary 1) to estimate the spending levels required to achieve the MDGs, 2) programme those spending levels into the fiscal budget, and 3) devise a macro framework that stimulates the growth rates that could sustain those spending levels. This Country Study has focused, so far, on the second objective. The full Zambia report provides some general guidelines for establishing the appropriate macro framework to achieve the MDGs (see Weeks et al. 2006). In this section we review some of its major points.

Such a macro framework has to confront the possibility that the proposed MDG funding measures could have negative effects on the economy. The most important of these would be 1) crowding out effects of an increased fiscal deficit; 2) private sector disincentives because of higher taxation; 3 ) inflationary pressures created by the increased government spending; and 4) the 'Dutch Disease' effects of a higher level of ODA (see McKinley 2005). 
Taking the MDGs seriously suggests that none of these potential difficulties should be treated as 'trump cards'. For example, the possibility of inflationary effects arising from a larger fiscal deficit is not an argument against increasing deficits, but an issue for empirical investigation. Moreover, empirical evidence substantiating that deficits above a certain level would reduce growth should not be viewed as precluding deficits above this so-called 'trigger' level. ${ }^{20}$ Rather, the size of the negative growth effect should be assessed, and compared to the impact of policies that could compensate for it. Even if moderate inflation could be shown to have a negative growth effect, for example, the relevant policy issue is the size of the effect in each country, and the possibility of implementing policies to counter it without reducing MDG expenditures. ${ }^{21}$

Let us examine, in turn, each of these four concerns about the impact of an MDG-based macro framework for Zambia. First, the full Zambia report recommends that the government deficit be expanded to three per cent of GDP. It suggests that the increase in public borrowing should be used for public investment, which would help relieve supply constraints on growth and stimulate private investment.

Thus, if carefully planned, then MDG-oriented public investment should, in fact, not 'crowd-out' private investment, but 'crowd it in'. Within this context, the report also calls for ending the government practice of 'cash budgeting', which restricts the ability of the government to finance investment projects since they require a sustained commitment of financing over a lengthy period of time.

Secondly, the full report recommends an increase in the corporate tax. It calls, in particular, for ending tax exemptions on copper production. Imposing a standard levy on copper should not have an adverse impact on exports since the global market for the commodity is characterised by excess demand. In other words, raising corporate taxes under current circumstances should not have significant disincentive effects on the private sector.

Thirdly, the full report maintains that if Zambia hopes to accelerate growth to seven per cent per annum, it should abandon restrictive inflation targeting, which currently is targeting a five per cent annual inflation rate. Targeting such an unreasonably low inflation rate entails a monetary policy geared to maintaining high real rates of interest. In contrast, the full report recommends that the Bank of Zambia lower its base rate (from its mid-2006 level of eight per cent) and impose regulations on commercial banks to narrow the gap between its base rate and their commercial lending rates. For Zambia to generate a much faster rate of economic growth, it needs a monetary policy that accommodates expansionary fiscal policy.

Fourthly, the full report also addresses the possibility of 'Dutch Disease' effects. Zambia's current high interest rate policy (in conjunction with tight fiscal policies) contributes to the appreciation of its currency, the Kwacha, which is threatening to dampen the growth of noncopper exports and tourism. A major factor that most analysts suspect is driving appreciation is the boom in copper prices. The full report maintains that a significant share of the appreciation is due to an inflow of portfolio capital that is speculating on copper prices and is encouraged by high real rates of interest. Hence, debt relief, or ODA for that matter, is not likely to be a major factor in causing appreciation.

Achieving a faster rate of economic growth, as recommended by the full report, could help mitigate pressures for appreciation by drawing in additional imports. The full report also urges the Bank of Zambia to publicly announce a policy of weakening the Kwacha and to 
utilize exchange-rate operations to systematically support this objective. It also advises that creating a 'copper fund' (similar to petroleum funds in oil-exporting countries) could help stabilize the monetary impact of foreign-exchange earnings from copper exports.

The growth-oriented strategy recommended by the full report implies that fiscal policy will be derivative from the MDG framework instead of being a constraint on its implementation (as is the case now). Once accelerated growth and substantial poverty reduction are set as the overriding goals of economic policies, a social cost-benefit analysis can be conducted of the potentially negative effects of crowding out, private-sector disincentives, inflation and exchange-rate appreciation,.

The full report maintains that such an analysis should seek to identify policies that 1) are consistent with ambitious MDG-oriented growth and poverty reduction targets and 2) can, moreover, counter possible adverse effects. It has offered several recommendations on fiscal, monetary and exchange-rate policies that could fulfil both criteria. In effect, this strategic approach would place the MDGs in the 'driver's seat' of economic policies. Hence, an MDG framework, which is oriented to accelerated growth and human development, is likely to identify more ambitious economic policies than those imposed by the current conditionalities focused on maintaining macroeconomic stability.

\section{CONCLUDING REMARKS}

This Country Study has used an MDG framework to critically examine fiscal policies in Zambia. It has noted that the Zambian government enjoys very little 'policy space', namely, the ability to choose its own fiscal policies. Instead, it is tightly hemmed in by an array of external conditionalities, the sum of which determines virtually all of its major economic policies. These conditionalities continue to perpetuate themselves despite donor assurances that the Poverty Reduction Strategy Paper process accords governments 'national ownership' of their poverty-reduction policies.

Despite such problems, Zambia appears, at first glance, to be in a very advantageous position because it has already received HIPC debt relief and expects to obtain dramatic G-8 debt relief by end 2006. However, this Country Study has found that when all calculations are carried out and attendant conditionalities on policymarking are taken into account, HIPC debt relief provides marginally less fiscal space, rather than more. Once Zambia receives G-8 debt relief, it will gain more fiscal space but this amount will be negligible, namely, less than one per cent of GDP.

This does not imply that this debt relief could not be helpful. What these projections underscore is that such relief would be decidedly more helpful if international donors continued, at least, their present levels of assistance, instead of reducing them, and removed many of the economic conditionalities that prevent the Zambian government from taking advantage of debt relief.

Increasing Official Development Assistance would make an important contribution to financing the expenditures needed to meet Zambia's MDG targets. Drawing on a national study of MDG costing in Zambia, the Country Study notes that under assumptions of moderate economic growth, i.e., 3.7 per cent per annum, additional financing equivalent to 8.8 percentage points of GDP would be needed to expand government expenditures so as to reach the MDGs. 
If economic growth accelerated to seven per cent per annum, this financing gap would fall to 7.5 percentage points. It would likely fall even more than this estimate since public revenue would probably rise and expenditures necessary for MDGs would probably fall as a result of the positive income effect of more rapid growth on MDG achievement. In order to finance the increase in government expenditures, the Country Study recommends a diversified strategy that relies primarily on mobilizing more domestic tax revenue, increasing domestic borrowing to finance a larger fiscal deficit and securing more external grant assistance. Such a financing strategy would not be inordinately reliant on ODA.

The Country Study concludes with a series of recommendations on a macro framework that would support the government's efforts to significantly expand expenditures to attain the MDGs. While such an MDG-oriented macro framework would incorporate greater mobilization of public revenue and higher fiscal deficits (up to three per cent of GDP), it would also accommodate moderately higher inflation rates, foster lower real rates of interest and entail purposeful management of the exchange rate in order to contain appreciation of the Kwacha.

Such expansionary policies are designed to help Zambia reach the ambitious target of a ten-year rate of growth of seven per cent per annum, which would enable it to halve extreme income poverty by 2015. Taken together, such policies are, concomitantly, designed to counter many of the adverse effects that an orthodox preoccupation with macroeconomic stability would regard as likely outcomes.

While more expansionary policies might cause moderately higher inflation (e.g., 5-15 per cent), this effect should not hamper the achievement of faster growth. While an MDG focus might entail a larger public investment programme, such a scaling up of expenditures should crowd in private investment, instead of crowd it out. This is likely to be the case insofar as MDG-focused investments improve human capabilities and expand economic infrastructure. Private investment is also likely to increase because of lower real lending rates of interest, induced by the abandonment of excessively low inflation targets.

An MDG-oriented macro framework is also intended to raise more public revenue in order to finance increased domestic expenditures. While this Country Study recommends more corporate taxes, it does not expect that such increased taxation will deter private output and investment. In particular, such deterrence is not likely to apply to the booming copper sector, which currently enjoys exemption from corporate taxes.

Because the faster growth that such a strategy fosters should pull in more imports (creating more demand for foreign exchange), such an effect should weaken the speculative forces appreciating the Kwacha. Purposeful management of the exchange rate, based on the central bank's current large holdings of reserves, could also help contain such appreciation. The abandonment of restrictive inflation targets and the lowering of real rates of interest will also reinforce such exchange-rate management. 


\section{REFERENCES}

Adam, Christopher S., and David L. Bevan (2005). 'Fiscal Deficits and Growth in Developing Countries,' Journal of Public Economics, no. 89.

Dagdeviren, Hulya, Rolph van der Hoeven and John Weeks (2002). 'Redistribution Matters: Growth for Poverty Reduction,' Development and Change, Number 33 (3).

IMF (2004a). Monetary Policy Implementation at Different Stages of Market Development: Country Cases and Appendices - Supplementary Information. IMF website.

IMF (2004b). Zambia: Selected Issues and Statistical Appendix. IMF Country Report No. 04/160, IMF website.

IMF (2004c). Zambia, Joint Staff Assessment of PRSP Progress Report. IMF Country Report No. 04/179: Washington DC: IMF.

IMF (2005a). Zambia: Enhanced Initiative for Heavily Indebted Poor Countries - Completion Point Document. IMF Country Report No. 05/137, IMF website.

IMF (2005b). Zambia: Second Review Under the Three-Year Arrangement under the Poverty Reduction and Growth Facility and Request for Waiver and Modification of Performance Criteria, and Financing Assurances Review - Staff Report; Staff Statement; Press Release on the Executive Board Discussion; and Statement by the Executive Director for Zambia. IMF Country Report No. 05/138, IMF website.

Kakwani, Nanak, and Hyun H. Son (2006). 'How Costly Is It to Achieve the Millennium Development Goal of Halving Poverty between 1990 and 2015,' Working Paper \#19, May, International Poverty Centre, Brasilia.

Khan, Mohsin S., and Abdelhak S. Senhadji (2001). 'Threshold Effects in the Relationship between Inflation and Growth,' IMF Staff Papers \#48, Washington D.C.: Washington.

Klugman, Jeni (2002). A Sourcebook for Poverty Reduction Strategies (two-volume set), Washington D.C.: World Bank.

McKinley, Terry (2005). 'Why Is the Dutch Disease Always a Disease?' Working Paper \#10 of the International Poverty Centre, November, Brasilia.

Ministry of Finance and National Planning (MFND) (2006). National Development Plan, Chapter 52 (draft). Lusaka: Government of Zambia.

Ministry of Finance and National Planning (2005). Macroeconomic Indicators (1997-2005). Lusaka: Government of Zambia.

Mphuka, C. (2005). The Cost of Meeting the MDGs in Zambia. Lusaka: CSPR \& CCJDP.

Situmbeko, L.C., and J.J. Zulu (2004). Zambia Condemned to Debt: How the IMF and the World Bank Have Undermined Development. World Development Movement, London.

United Nations Development Programme, UNDP (2005). Millennium Development Goals, Zambia, Status Report 2005. Lusaka: UNDP.

Weeks, John (2006). 'Conditionality, Development Assistance and Poverty: Reforming the PRS Process,' in Alberto Paloni and Maurizio Zanardi (eds), The IMF, World Bank and Policy Reform, Abingdon, UK: Routledge. 
Weeks, John, Victoria Chisala, Alemayehu Geda, Hulya Dagdeviren, Terry McKinley, Alfredo Saad-Filho and Carlos Oya (2006). Economic Policies for Growth, Employment and Poverty Reduction: Case Study of Zambia. Supported by the Poverty Group and the International Poverty Centre of UNDP, Brasilia: UNDP.

\author{
World Bank (2002). Zambia: Country Assistance Evaluation, Report No. 25075, Washington D.C.: \\ World Bank Operations Evaluation Department.
}

\title{
NOTES
}

1. In early 2006, the Ministry of Finance and National Planning estimated that on the assumption of full implementation of G-8 debt cancellation, the total debt stock would fall to US\$747 million, of which Paris Club bilateral debt would be US\$ 110 million, bilateral non-Paris Club US\$280 million, and multilateral US\$356 million. The only creditors that Zambia would owe over fifty million dollars would be the European Investment Bank ( 25 per cent of the US\$ 747 million), China (20 per cent), Russia (15 per cent), and the International Fund for Agricultural Development (11 per cent). IMF and World Bank debts would be completely cancelled. The source for these numbers is information provided by the ministry. 2. For a global approach to MDG costing whose methodology has informed this study, see Kakwani and Son 2006.

3. After the unilateral declaration of independence by the white regime in so-called Rhodesia, the transport links through both Southern Rhodesia and South Africa were severely disrupted. Support for the liberation movement in Mozambique closed that outlet to the sea. Before the completion of the trans-Tanzanian railroad, the Zambia national copper enterprise was forced in some periods to export copper ore by air. See discussion in Weeks, et. al. 2006.

4. Large year-to-year fluctuations were the result of the government's debt strategy, which was designed by the international financial institutions. A report by the Operations Evaluations Department of the World Bank judged the strategy to be unsound (World Bank 2002).

5. A WB web page describes the debt sustainability analysis as follows: Reducing the threshold for a poor country's external debt to be considered unsustainable was an important area of consensus of the HIPC review, and a major element of the enhancement endorsed in September 1999. As with the original framework, external debt sustainability will continue to be determined by a Debt Sustainability Analysis (DSA) prepared by the debtor country, World Bank and the IMF, to determine whether a country is facing an unsustainable debt situation after the full application of traditional debt relief mechanisms. The new framework also allows for two related set of criteria to be considered. The first, which will continue to apply to most HIPCs, is the ratio of a country's debt to its exports. Under the enhanced framework, sustainable debt-toexport levels are defined at a fixed ratio of 150 percent (on a net present value basis, or NPV). The second, for those HIPCs with very open economies where exclusive reliance on external indicators may not adequately reflect the fiscal burden of external debt, an NPV debt-to-export target below 150 can be recommended if the country concerned meets two criteria at the decision point: an export-to-GDP ratio of at least 30 percent and a minimum threshold of fiscal revenue in relation to GDP of 15 percent. For these countries, the NPV debt-to-export target will be set at a level which achieves 250 percent of the NPV debt-to-revenue ratio at the decision point. (http://www.worldbank.org/hipc/faq/faq.html).

6. The percentages by year are given as 7.3, 7.1, 5.5, 2.9 and 5.9, respectively, with the penultimate 'estimated' and the last 'projected' (IMF 2005a, Table 2).

7. For a fuller discussion, see Weeks (2006).

8. An example was the inflation conditionality, which implied high domestic interest rates, though interest rate levels were not subject to conditionality. The high interest rates, in turn, resulted in high domestic debt service, which limited poverty reducing expenditures at the same time that international agencies in their rhetoric called for the government to give these priority.

9. Officials at the Ministry of Finance and National Planning cited examples of cost increases and abandonment of projects directly resulting from cash budgeting requirements (interviews conducted in November 2004).

10. The IMF extends its projections to 2023. Such a long period involves too high a degree of uncertainty for the estimation purposes of this report. The five-year period 2006-2010 is compared to 2000-2004, rather than 2001-2005 because relevant data for 2005 were not available when this report was written.

11. On page 35 (Table 12) of the IMF's Selected Issues document (IMF 2004a), the following numbers are given for 2000-2003 for the category of 'revenue and grants' as a proportion of GDP: 25.1, 24.8, 26.2 and 25.0. The percentages for the category 'revenue' alone are 19.4, 19.1, 17.9 and 18.1. Thus, 6.7 is the average difference over the four years. The Ministry of Finance and Economic Planning reported 24.2 and 18.5 per cent, respectively, for 2004 . The 'decision point' document provides figures only for the category 'revenue excluding grants'. The only mention of grant levels is in Box 2 (see quotation in Table 4).

12. On its HIPC web site (in 2005), the World Bank presents several 'frequently asked questions' (FAQ). In reply to the question, does debt relief replace development assistance, the following answer is given: No. HIPC debt relief can be fully 
beneficial to a country only if it is provided in addition to previous rates of development assistance. A comparison of current debt service payments and concessional assistance illustrates how important continued aid programmes are to these countries. The ratio of gross inflows (from long-term debt and grants) to debt service paid averaged about two-to-one for the HIPCs as a group during the 1990s, and ranged upwards of four-to-one in half of these countries. Annual net transfers to the HIPCs on medium- and long-term resource flows (including grants) averaged about 10 percent of GNP over the 1990-96 period. Debt reduction must be additional to development assistance. (Emphasis added, www.worldbank.org/hipc).

13. Eight per cent for wages and salaries was the upper limit conditionality set by the IMF. The 2006-10 overall deficit is set out in Box 3 under the heading 'fiscal policy'. 'Net change in fiscal space' is defined as the change in the level of government expenditure net of debt service, funded by revenue, grants and domestic borrowing. The increase in revenue and decline in debt service increased fiscal space, while the fall in grants and the deficit decreased fiscal space. The IMF source explains the parameters of the 2006-10 budget as follows:

The 3-year PRGF-supported programme is anchored on reducing government's domestic borrowing to 0.6 per cent of GDP in 2007, before falling to near zero over the long term. Government revenues are projected to rise gradually to 19 per cent of GDP by 2011 and continue growing to 20 per cent of GDP by 2016, before holding steady at that level. Government spending, excluding externally financed projects, is expected to gradually fall to about one percentage point of GDP above government revenues, with the balance financed by budget support grants and loans. Externally financed projects are projected to decline gradually to 3-4 per cent of GDP over the long term, with grants making up an increasing share of the total. (IMF 2005, Box 3)

The G-8 initiative differs from HIPC because debt service falls to one tenth of one per cent of GDP (estimate by the Ministry of Finance and National Planning, based on the assumption that total debt will fall to below US\$500 million).

14. This section draws on the draft Chapter 52 of the National Development Plan of the Zambian government, due for release in August 2006.

15. The MDG 'gap' is the difference between the 2005 budget allocation and the cost estimate of achieving the MDG (both as a per cent of GDP). This makes the strong assumption that all 2005 expenditures in the relevant categories contributed to achieving the MDGs. The MDG costing categories are hunger, education, gender equality, health, water \& sanitation, improving the lives of slum dwellers, energy, roads and 'other' (Mphuka 2005, 35). The total estimate is 24 per cent of GDP ( 25 per cent in the original source, presumably due to rounding). The percentage estimates in the source are allocated as follows: hunger to social safety nets; improving lives of slum dwellers to social safety nets; roads equally divided between construction and transport; and education, health, water \& sanitation, and energy to the same budget categories. The allocation is for presentation and does not affect the calculation.

16. This is stressed in the draft National Development Plan:

The [NDP] will largely be financed through three sources. These are: (i) Domestic Revenues; (ii) External Grants; and to some extent (iii) Borrowing, both domestically and externally. (MFND 2006, 1)

17. While WTO rules do not dictate the tariff levels at which a country has to enter the organisation, once a member, a government should not raise those rates. The benefit of hindsight suggests that the Zambian government should have entered the WTO with higher rates. Officials of the Zambian Privatisation Agency concluded that excessive trade liberalisation was the main cause of the collapse of many manufacturing enterprises (interviews reported in Weeks, et. al. 2006, Chapter 2).

18. Soon after privatisation, the most important copper company abandoned its mines. The privatisation contract, which had World Bank oversight of its drafting, provided no penalty for such unilateral action. The World Bank's role in the privatisation of copper came under sharp criticism from the World Bank's own evaluation department (World Bank 2002).

19. As an illustration, assume that the estimated expenditure to meet all the MDGs is US\$ 30 per capita for each year during 2007-2015. Also assume total GDP per capita to be $\$ 100$ and population growth to be 1.5 per cent per annum. If GDP grew slower than 1.5 per cent, the necessary expenditures would rise as a proportion of GDP. If GDP grew faster than 1.5 per cent, the necessary expenditures would decline as a proportion of GDP. Of course, if GDP grew 1.5 per cent, the share would remain constant.

20. In a 2005 paper, Adam and Bevan report a negative 'threshold effect [on growth] at a level of the deficit around 1.5 per cent of GDP,' based on cross-country regressions. Their conclusion is, however, highly qualified: While there appears to be a growth payoff to reducing deficits to this level, this effect disappears or reverses itself for further fiscal contraction. The magnitude of this payoff, but not its general character, necessarily depends on how changes in the deficit are financed... and on how the change in the deficit is accommodated elsewhere in the budget. (Adam and Bevan 2005, p. 571).

21. In a 2001 IMF Staff Paper, Khan and Senhadji report that ' $[t]$ he threshold level of inflation above which inflation significantly slows growth is estimated at...11-12 per cent for developing countries' (Khan and Senhadj 2001, 1). However, the effect is quite small. For example, consider the IMF projected growth rate for Zambia of five per cent, and assume that increasing the deficit increases inflation. According to the Khan and Senhadji statistics, an increase in the rate of inflation from 11 per cent (the threshold, which was also about Zambia's inflation rate in 2006) to 20 per cent would reduce the growth rate by 0.47 percentage points. This implies an arc elasticity of -0.11 . Ceterius paribus, from the threshold level, a doubling of the inflation rate would reduce the growth rate from an initial five per cent to 4.4 per cent (see Khan and Senhadji 2001, Table 3). With a velocity of money of four, a nine per cent increase in inflation requires an increase in the fiscal deficit of 2.25 percentage points of GDP. For any realistic capital-output ratio, this decline in the growth rate could easily be overcome by using the increased funds from the deficit for the financing of productive public investment. 
International Poverty Centre SBS - Ed. BNDES, $10^{\circ}$ andar 70076900 Brasilia DF Brazil

povertycentre@undp-povertycentre.org www.undp.org/povertycentre Telephone +55 6121055000 Fax +55 6121055001 